\title{
sciendo
}

\section{Impact of Selected Socio-Demographic Characteristics on Branded Product Preference in Consumer Markets}

\author{
Pavol KRAL \\ University of Zilina, Faculty of Operation and Economics of Transport and Communications, \\ Department of Economics, Univerzitna 1,010 26 Zilina, Slovak Republic \\ pavol.kral@fpedas.uniza.sk \\ Katarina JANOSKOVA \\ University of Zilina, Faculty of Operation and Economics of Transport and Communications, \\ Department of Economics, Univerzitna 1,010 26 Zilina, Slovak Republic \\ George LAZAROIU \\ The Cognitive Labor Institute, New York, USA; Spiru Haret University, Bucharest, Romania

\begin{abstract}
Petr SULER
School of Expertness and Valuation, Institute of Technology and Business in České Budějovice, Okružní 517/10, 37001 České Budějovice, Czech Republic
\end{abstract}

\begin{abstract}
A$ successful brand is one of the most valuable resources a company has. Should the brand become powerful, it is supposed to reflect rational and emotional expectations of consumers, which, however, might change over time. The ability to recognize the consumers changing attitudes towards the brand is thus the prerequisite for effective brand management. The aim of the paper is to identify the correlation between selected socio-demographic characteristics and preferences for branded products by Slovak consumers, using a mathematical and statistical modelling. For this purpose, a comprehensive marketing survey has been carried out involving Slovak consumers of the minimum age of 16. The findings of the survey show a direct correlation, but varying in character and intensity, between the selected socio-demographic characteristics of respondents (gender, age, education, income) and their preferences for branded products; and based on the survey findings, the paper then provides further recommendations for non-adopting current trends in attitudes and preferences towards brands on Slovak consumer markets, that are recognized as significant sales and marketing tools, into the branding processes. However, considering different cultural, social and economic situations of different markets, it is not possible to generalize about the results of the paper as also being relevant for other markets. A successful brand in the domestic market is not a prerequisite of success in global markets.
\end{abstract}

Keywords: brand, consumer attitudes, brand preference, Pearson Chi-Square.

Please cite the article as follows: Kral, P., Janoskova, K., Lazaroiu, G., Suler, P. (2020), "Impact of Selected Socio-Demographic Characteristics on Branded Product Preference in Consumer Markets", Management \& Marketing. Challenges for the Knowledge Society, Vol. 15, No. 4, pp. 570-586, D0I: 10.2478/mmcks-2020-0033. 


\section{Introduction}

Attitudes are considered significant incentive determinants, affecting consumer behaviour accordingly, since they reflect consumer preferences (positive, negative) for the brand. The attitudes, however, cannot be noticed directly, but they can be recognized from the way the consumer behaves and/or communicates. In general, the attitudes are determined by the consumer's direct experience with the brand and the information about the brand he/she would receive.

The concept of branding is considered the effective marketing tool since the concept first appeared. The brand plays the key part in consumer decision-making on products, and it is crucially important to both producers and consumers. The consumers find the brand to be the significant quality of the product, and they are likely to opt for the proven brand rather than even considering the other brands available. Thus, the brand shall be considered the attribute of great importance when it comes to the consumer decisionmaking about the product.

Brand management has to reflect the trends in the business environment of a company. Moreover, the socio-demographic characteristics of consumer markets shall also be considered the key determinants that effective branding strategies have to reflect.

This research aims at identifying the correlation between selected sociodemographic characteristics (gender, age, education, income) and preferences for the branded products by the Slovak consumers, using a mathematical and statistical software. For this purpose, a comprehensive marketing survey has been carried out involving Slovak consumers. The results of the survey show a direct correlation, but varying in character and intensity, between the selected socio-demographic characteristics of respondents and their preferences for branded products.

\section{Literature Review}

In this context, it is vital for companies to understand how consumers think, their reasons for buying one product or another, one brand or another, how they decide between multiple alternatives, etc. The analysis of consumer attitudes, obtaining evidence from consumer assessments and behaviour can help companies consider strategies used to influence consumers to purchase goods and services and the leaders to explore new opportunities (Dima and Ghinea, 2016). For companies, brand loyalty is one of the critical factors associated with company longevity and success (Kuchinka et al., 2018).

A brand is a very broad concept. It is a combination of everything that a customer takes into account in the purchasing decision-making process. It is not only a trademark but also the associations that arise in the minds of consumers when remembering a specific brand. The brand strikes an emotion in consumers. This is a combination of consumer experience with the brand since the very first "touch" of the product (Krizanova et al., 2013). Today, branding is taken as a separate marketing tool (Dincă et al., 2019) and is a very important product attribute. It is the symbol and identifier of the product that differs from the competition (Moravcikova et al., 2017).

Brands can significantly impact consumers and levels of change. Branding has become the story of belonging and pervasion because it allows consumers to express their personality (interest, attitude likes and dislikes) through the brands they use. An examination of the relationship between brands and consumers emphasizes the 
interdependence between them, meaning that consumers contribute to brand development and success but also brands influence and determine consumer behaviour (Grubor and Milovanov, 2017).

Brands have a different meaning for each consumer, which helps develop the purchasing trends. In relation to the consumer, the brand consists of important elements. Mostly, it is the significance of a brand expressing the way the consumer perceives the brand within its rational and emotional advantages (Vysekalova and Mikes, 2009). All brands aiming at building a strong competitive position in the market need to be able to reinforce their image. This is the reason why managers have stressed brands engaging in activities such as advertising and public relations (Aaker 1996). Zambardino and Goodfellow (2007) argue that emotional customer perceptions are key constituents of the brand image. Brand image has been researched since the early 1950s. There are still differing views on its conceptualization and measurement (Park and Rabolt, 2009). However, several authors seem to agree on the conceptualization of brand image as the perceptions that customers associate with a specific brand. Brand image includes three types of customer associations with a brand (dimensions of brand image): 1. cognitive personal thoughts, beliefs and evaluations that customers relate to a brand, 2. emotional the feelings and emotions that customers develop toward a brand (joy, happiness, anger, excitement etc.), 3. sensory - reflect the physical senses (touch, sight, sound, smell, taste etc.) (Cho and Fiore, 2015). Many authors have shown that customers' positive feelings, emotions toward a brand have a positive impact on certain brand outcome variables, such as brand loyalty, brand equity, brand trust, positive brand market share etc. (Aurier and Séré de Lanauze, 2012; Bowden, 2011; Chaudhuri and Holbrook, 2001; Evanschitzky et al., 2006; Singh et al., 2012; Iglesias et al., 2011; Singh et al., 2012; Yang, 2012; Sierra et al., 2015; Nica and Taylor, 2017; Okuneviciute and Pranskeviciute, 2018). Favourable brand image positively influences many customer outcome variables, such as customer loyalty, customer purchase intentions, customer willingness to pay a premium price, positive wordof-mouth communications (Ogba and Tan, 2009).

In recent years, a philosophy shift has also occurred within brand management ideology (Popović et al., 2015) where brand owners have become interested in the need to enhance their brands both in socio-psychological and aesthetic ways. In many countries, brands have firmly diffused into all levels of our everyday lives as a glimpse through the news channels, magazines and social media shows (Levy and Luedicke, 2013).

In the current hyper-connected and transparent environment, customers have more access to the business practices of brands (Iglesias et al., 2013). Many authors are convinced that brand image and positive perception for the brand is a key antecedent of brand equity (Gill and Dawra, 2010; Kim et al., 2012). When customers develop relationships with certain brands, they can obtain recognition benefits, such as positive feelings and emotions, ego enhancement and group identification (Merz et al., 2009). These emotional and affective responses arise when the customers of a brand feel privileged and special because of their association with that particular brand (Wagner et al., 2009). Managers should encourage customers to share their personal experiences when interacting with the brand, using various available means such as social media, so that they can depict the recognition benefits that they are receiving from their engagement (Iglesias et al., 2019; Shackelford, 2018). According to Lei and Chu (1991) brand equity can be analysed from three different perspectives, namely consumer-based, product-based, and 
financial-based; we will refer to brand equity mainly from the customer-based perspective because, from this perspective, brand equity reflects how consumers perceive and react to a branded product or service versus an unbranded offering.

Brand equity adds value to a product or a service and contributes to companies' efforts to developing positive customer perception and achieving customer loyalty (Susanty and Kenny, 2015).

The effective marketing is also to change consumer's mind-set of the brand; and the following are some of the strategies (Richterova et. al, 2015):

a) consumer relative preferences towards brand change - to bring the benefits of different brands to different consumer groups; should the products be grouped based on the qualities (or benefits) they would bring to the target group, there is a higher potential for sellers to also convince the consumers preferring the only product from the group of the benefits of the other products from the group;

b) consumer attitude towards brand change - to provide systematic and relevant information about the brand in terms of highlighting of the key qualities of the product; the information shall be repeated for long enough time to make the consumer take over his/her fear of change, and thus to change his/her mind about their initial attitudes towards the brand;

c) assigning of qualities change - to assign such qualities that either have been ignored so far or would depend on innovations and/or technological trends, and so that the consumer would find significant enough to play the part in their decision-making about the product;

d) consumer overall attitude towards brand change - to change consumer attitudes towards the brand without affecting the product's qualities;

e) consumer attitude towards competitive brand change - to change consumer attitudes towards competitive brand based on the competitive brand review; however, the strategy is to be thought thoroughly prior implementing as it might turn to the competitive brand being put in the spotlight instead.

\section{Methodology}

An extensive marketing survey was carried out to determine the preferences and attitudes of Slovak consumers towards brands, i.e., to indicate key endogenous and exogenous factors determining the consumers' preferences for the brand within a thorough sector structure of the national economy and also to identify the triggers determining the consumers' attitudes towards the brand, using individual marketing mix tools.

The survey was carried out as part of the long-term research task, which was to work out the integrated financial-behavioural model for brand management to aid brand building in the specific conditions of the Slovak Republic. It is the survey as well as the survey findings thereof that reveal the brand positioning specificities within the selected sectors of the national economy, the specificities of consumer psychological profiles as well as the mechanisms of consumer decision-making about products.

The survey sample (hereinafter the target group) involved Slovak consumers, regardless of gender, social status, monthly income or place of residence. The collection of the data took place in March 2018. The simple random sampling method was used to select the sample. The only restriction in terms of the socio-demographics was set on the age of the respondents, i.e., the minimum age of 16 . 
The survey questionnaire consisted of 34 questions, mostly closed-ended (selective) questions, which tend to be more preferred by most respondents. Respondents expressed their preferences through the 5-point Likert scale. The questionnaire was divided into three parts from the point of view of the context, and which are as follows: the first part dealing with consumer preferences and attitudes towards brands in general, the second part addressing specific cost-saving scenarios in 4 selected areas: automobiles, banks, cola drinks and sportswear; and the last one mapping the socio-demographic characteristics of consumers, i.e. respondents, which are as follows.

- gender

- age

- place of residence

- other persons living in the common household

- education

- social status

- net monthly household income

The target group shall be considered large enough and equally balanced, involving 2,002 respondents (985 (49.2\%) males vs 1,017 females (50.8\%)) from all eight regions of the Slovak Republic. The average age is calculated at 39.8 years, and thus the target group shall be considered rather equal from the point of view of the age. As for the education, the highest frequencies are identified with the primary/vocational graduates $(1,071 ; 53.5 \%)$, then the secondary graduates follow $(687 ; 34.3 \%)$, and finally, the university graduates follow $(244 ; 12.2 \%)$. Furthermore, as for the social status, the highest frequencies are identified with the employees $(965 ; 48.20 \%)$; and, finally, the highest frequencies, regarding the net monthly income, are identified with the EUR 501-1,000 range.

Table 1 below provides more details on the socio-demographic characteristics of the target group.

Table 1. Selected Socio-Demographic Data Frequency Overview

\begin{tabular}{|c|c|c|c|c|c|c|}
\hline Gender & \multirow{2}{*}{\multicolumn{3}{|c|}{$\begin{array}{c}\text { male } \\
985(49 \%)\end{array}$}} & \multicolumn{3}{|c|}{ female } \\
\hline Frequency & & & & & $1,017(51 \%)$ & \\
\hline Age & $16-25$ & $26-35$ & $36-45$ & 46-55 & $55-65$ & over 66 \\
\hline Frequency & $438(22 \%)$ & $423(21 \%)$ & $377(19 \%)$ & $381(19 \%)$ & $293(15 \%)$ & $90(4 \%)$ \\
\hline Education & \multicolumn{2}{|c|}{ primary/vocational } & \multicolumn{2}{|c|}{ secondary } & \multicolumn{2}{|c|}{ university } \\
\hline Frequency & \multicolumn{2}{|c|}{$1071(53 \%)$} & \multicolumn{2}{|c|}{$687(34 \%)$} & \multicolumn{2}{|c|}{$244(12 \%)$} \\
\hline Social Status & student & employed & unemployed & $\begin{array}{c}\text { self- } \\
\text { employed }\end{array}$ & retired & $\begin{array}{c}\text { maternity } \\
\text { leave }\end{array}$ \\
\hline Frequency & $330(16 \%)$ & $965(48 \%)$ & $128(6 \%)$ & $123(6 \%)$ & $314(16 \%)$ & $142(7 \%)$ \\
\hline $\begin{array}{l}\text { Net Monthly } \\
\text { Household } \\
\text { Income } \\
\text { (EUR) }\end{array}$ & $<500$ & $501-1,000$ & $1,001-1,500$ & $1,501-2,000$ & $2,001-2,500$ & $>2,500$ \\
\hline Frequency & $342(17 \%)$ & $692(35 \%)$ & $558(28 \%)$ & 255 (13\%) & $88(4 \%)$ & $67(3 \%)$ \\
\hline
\end{tabular}

Since the survey turned to be rather massive as for the content, the following is to analyse only the limited scope of the survey, which is to evaluate the correlation between selected socio-demographic characteristics of the respondents and their attitudes (or preferences) towards the product brands (preferences for branded products over unbranded products, i.e., anonymous products). The acquired primary data enabled us to 
carry out the formulated statistical hypothesis test with the goal to identify mutual causalities between the selected socio-demographic characteristics of respondents and their opinions regarding brands or their behaviour respectively. The analysis and processing of primary data of the survey in this form provides new facts that have not been evaluated yet. For the purpose of formulating the conclusions and further recommendations the following statistical hypothesis have been put forward:

H1: There is no statistically significant correlation between the gender of consumers and their preferences for branded products over unbranded products

H2: There is no statistically significant correlation between the age of consumers and their preferences for branded products over unbranded products

H3: There is no statistically significant correlation between the education of consumers and their preferences for branded products over unbranded products

H4: There is no statistically significant correlation between the net monthly income of consumers and their preferences for branded products over unbranded products

The verification of the hypothesis was carried out using the Chi-Square test (IBM SPSS Statistics, ver. 25). The Pearson's chi-squared test of independence is tested at the significance level of 0.05 . If the test confirmed the dependence between the variables, its intensity was measured using the Cramer's V coefficient, which is the most used contingency rate. The resulting value of Cramer's $\mathrm{V}$ coefficient then distinguishes three degrees of dependence: (1) a weak dependence - the value is between 0 and 0.3 ; (2) a moderate dependence - the value of 0.3 - 0.8 and (3) a strong dependence - value from 0.8 to 1 (Rimarcik, 2007). The independence test benchmark criteria were met in all cases; one of the questions, however, had to be answered on the rating scale from 1 to 5 (1 completely disagree, 3 - rather neutral, 5 - absolutely agree; where 1 to 2 imply rather negative attitude, and, otherwise, 4 to 5 imply rather positive attitude towards the branded product), which was to benchmark the statistical hypotheses, that were tested afterwards, using the independence test.

\section{Empirical Data / Results}

Given the survey data, the first socio-demographic characteristics subject to analysis was gender, which were to determine the effect of the gender on consumers' preferences for branded products. The hypothesis is as follows:

Ho: There is no statistically significant correlation between the gender of consumers and their preferences for branded products over unbranded products.

$H_{1}$ : There is statistically significant correlation between the gender of consumers and their preferences for branded products over unbranded products.

The contingency table below (Table 2) provides the frequencies of respondents' answers.

Table 2. Gender vs Branded Products Preferences

\begin{tabular}{|c|c|c|c|c|c|c|c|c|}
\hline & & & 1 & 2 & 3 & 4 & 5 & Total \\
\hline \multirow{4}{*}{ Sex } & Woman & Count & 128 & 224 & 425 & 176 & 64 & 1017 \\
\hline & & Expected Count & 95.5 & 217.4 & 400.8 & 234.2 & 69.1 & 1017,0 \\
\hline & Man & Count & 60 & 204 & 364 & 285 & 72 & 985 \\
\hline & & Expected Count & 92.5 & 210.6 & 388.2 & 226.8 & 66.9 & 985,0 \\
\hline \multirow[t]{2}{*}{ Total } & & Count & 188 & 428 & 789 & 461 & 136 & 2002 \\
\hline & & Expected Count & 188,0 & 428.0 & 789.0 & 461.0 & 136.0 & $2,002.0$ \\
\hline
\end{tabular}


The survey sample is considered rather equally balanced when it comes to gender, thus making the sound basis for generalising on the findings and formulating further conclusions. Regarding the question on branded products preferences, both genders rated the question as of the limit values, i.e., 1 (completely disagree) and 5 (absolutely agree), the least; and, on the contrary, the highest frequencies were identified with those who rated the question as 3 (rather neutral) for both genders. This might be due to respondents being rather cautious to put forward their attitude or the consumers' different level of preference of branded products on different consumer markets respectively. Should the question, if rated 4 to 5 , is thus to indicate the preferences of the branded products, it is then possible to assume that male consumers, compared to female consumers, tend to prefer the branded products much more significantly, which is made clear by the higher cumulated answers frequencies of up to $48.8 \%$.

The column Asymptotic Significance (2-sided) in Table 3 includes the resulting pvalue of the independence test on correlation between the gender of consumers and their preferences for branded products over unbranded products. Upon the p-value, which is lower than the current significance level standard value of 0.05 , the $\mathrm{H}_{0}$ null hypothesis regarding the independence of the variables is rejected and the alternate $\mathrm{H}_{1}$ hypothesis is accepted, i.e., the variables are dependent. Therefore, it is possible to consider that the consumer' gender in terms of socio-demographic characteristics is determining the preferences and attitudes of consumers towards branded products. Male consumers, however, generally tend to opt for the branded products to a greater extent.

Table 3. Chi-Square Tests 1

\begin{tabular}{lrrr}
\hline & Value & \multicolumn{2}{c}{$\begin{array}{cr}\text { Asymptotic Significance (2- } \\
\text { sided) }\end{array}$} \\
\hline Pearson Chi-Square & $55.992^{*}$ & 4 & .000 \\
Likelihood Ratio & 56.795 & 4 & .000 \\
Linear-by-Linear Association & 35.879 & 1 & .000 \\
N of Valid Cases & 2,002 & & \\
\hline
\end{tabular}

* 0 cells $(0,0 \%)$ have expected count less than 5 . The minimum expected count is 66.91 .

Source: Authors' development.

Table 4 provides the Cramer's V coefficient and the contingency coefficient, bringing more light on gender vs branded products preference correlations. In terms of quantified values of the coefficients involved, it proves a weak dependence, i.e., the preference for branded products depends on the consumer's gender, which is why the coefficient significance test of the variables is statistically significant, i.e., the dependence between the variables is weak, though statistically significant (systematic), and thus shall not be considered the random phenomenon (the approximate significance value is less than 0.05).

Table 4. Directional Measures 1

\begin{tabular}{|c|c|c|c|c|c|}
\hline & & Value & $\begin{array}{r}\text { Asymptotic } \\
\text { Standard Errora }\end{array}$ & Approximate $\mathbf{T}^{\mathbf{b}}$ & $\begin{array}{r}\text { Approximate } \\
\text { Significance }\end{array}$ \\
\hline \multirow[t]{2}{*}{ Nominal by Nominal } & Cramer's V & .167 & & & 000 \\
\hline & $\begin{array}{l}\text { Contingency } \\
\text { Coefficient }\end{array}$ & .165 & & & 000 \\
\hline $\mathrm{N}$ of Valid Cases & & 2,002 & & & \\
\hline
\end{tabular}

a. Not assuming the null hypothesis. 
b. Using the asymptotic standard error assuming the null hypothesis.

c. Based on normal approximation.

Source: Authors' development.

The other socio-demographic characteristics subject to analysis was gender; and the hypothesis is as follows:

Ho: There is no statistically significant correlation between the age of consumers and their preferences for branded products over unbranded products.

$H_{1}$ : There is statistically significant correlation between the age of consumers and their preferences for branded products over unbranded products.

The contingency table below (Table 5) provides the frequencies of respondents' answers by individual age intervals.

Table 5. Age vs Branded Products Preferences

\begin{tabular}{|c|c|c|c|c|c|c|c|c|}
\hline & & & 1 & 2 & 3 & 4 & 5 & Total \\
\hline \multirow[t]{12}{*}{ Age } & \multirow[t]{2}{*}{ 16-25 } & Count & 52 & 108 & 134 & 115 & 29 & 438 \\
\hline & & Expected Count & 41.1 & 93.6 & 172.6 & 100.9 & 29.8 & 438,0 \\
\hline & \multirow[t]{2}{*}{$26-35$} & Count & 41 & 108 & 142 & 96 & 36 & 423 \\
\hline & & Expected Count & 39.7 & 90.4 & 166.7 & 97.4 & 28.7 & 423,0 \\
\hline & \multirow[t]{2}{*}{$36-45$} & Count & 31 & 69 & 157 & 86 & 34 & 377 \\
\hline & & Expected Count & 35.4 & 80.6 & 148.6 & 86.8 & 25.6 & 377,0 \\
\hline & \multirow[t]{2}{*}{ 46-55 } & Count & 28 & 58 & 188 & 84 & 23 & 381 \\
\hline & & Expected Count & 35.8 & 81.5 & 150.2 & 87.7 & 25.9 & 381,0 \\
\hline & \multirow[t]{2}{*}{$56-65$} & Count & 29 & 68 & 120 & 65 & 11 & 293 \\
\hline & & Expected Count & 27.5 & 62.6 & 115.5 & 67.5 & 19.9 & 293,0 \\
\hline & \multirow[t]{2}{*}{ over 65} & Count & 7 & 17 & 48 & 15 & 3 & 90 \\
\hline & & Expected Count & 8.5 & 19.2 & 35.5 & 20.7 & 6.1 & 90,0 \\
\hline \multirow{2}{*}{\multicolumn{2}{|c|}{ Total }} & Count & 188 & 428 & 789 & 461 & 136 & 2002 \\
\hline & & Expected Count & 8,5 & 19.2 & 35.5 & 20.7 & 6.1 & 90.0 \\
\hline
\end{tabular}

The minimum age of the respondents of the survey was set to 16. There were 6 age intervals set, in 10 year increments, and considered large enough to analyse the effect of age on consumers' preferences for branded products. The survey sample was rather equally balanced in terms of intervals, except for the interval no. 6 (respondents aged over 65). Nevertheless, for all age intervals, the highest answers frequencies were identified with the questions rated as 3 . The values indicate interesting trends. The respondents of the first two age intervals do not consider the branded products their priority, even though the difference in values, in favour of the branded products, is not that significant. However, the turning point comes with the age intervals of 36-45 and 46-55, when the respondents' preferences are to change in favour of the branded products; and, on the contrary, the respondents' preferences for the branded products are then to decrease with the higher age intervals (over 56). The cumulative answers frequencies, if rated 4 and 5 by those in the age interval of 16-25, make $32.9 \%$ of the total answers frequencies within the interval, whereas for those in the interval over the age of 65 , it is only $20.0 \%$. Thus, the rule the higher the age, the more prevalent the preference for the branded products applies, before eventually decreasing; however, such preference difference shall not be considered significant.

The resulting $p$-value of the independence test on correlation between the age of consumers and their preferences for branded products (Table 6) is lower than the significance level standard value. The null hypothesis is rejected and the alternate $\mathrm{H}_{1}$ hypothesis regarding the dependency of the variables is accepted. Therefore, it is possible 
to consider the consumer's age in terms of the socio-demographic characteristic as determining the consumer's preferences for branded products vs unbranded products. Moreover, consumer preferences tend to culminate between the ages of 30 to 50 .

Table 6. Chi-Square Test 2

\begin{tabular}{lccc}
\hline & Value & df & $\begin{array}{c}\text { Asymptotic Significance } \\
\text { (2-sided) }\end{array}$ \\
\hline Pearson Chi-Square & $61.495^{*}$ & 20 & .000 \\
Likelihood Ratio & 62.592 & 20 & .000 \\
Linear-by-Linear Association & .007 & 1 & .934 \\
N of Valid Cases & 2,002 & & \\
\hline
\end{tabular}

* 0 cells $(0,0 \%)$ have expected count less than 5 . The minimum expected count is 6.11 .

Source: Authors' development.

Both the Cramer's V coefficient and the contingency coefficient values shown in Table 7 prove a weak dependency between the age of consumers and their preferences for branded products. The dependence between the variables is weak, though statistically significant, and thus the random phenomenon shall not be considered.

Table 7. Directional Measures 2

\begin{tabular}{|c|c|c|c|c|c|}
\hline & & Value & $\begin{array}{r}\text { Asymptotic } \\
\text { Standard Error }\end{array}$ & Approximate $\mathrm{T}^{\mathrm{b}}$ & $\begin{array}{r}\text { Approximate } \\
\text { Significance }\end{array}$ \\
\hline \multirow[t]{2}{*}{ Nominal by Nominal } & Cramer's V & .088 & & & ,000 \\
\hline & $\begin{array}{l}\text { Contingency } \\
\text { Coefficient }\end{array}$ & .173 & & & ,000 \\
\hline $\mathrm{N}$ of Valid Cases & & 2,002 & & & \\
\hline
\end{tabular}

a. Not assuming the null hypothesis.

b. Using the asymptotic standard error assuming the null hypothesis.

c. Based on normal approximation.

Source: Authors' development.

The other socio-demographic characteristics subject to analysis was education, i.e., the effect of the level of education on consumers' preferences for branded products; and the hypothesis is as follows:

Ho: There is no statistically significant correlation between the education of consumers and their preferences for branded products over unbranded products.

$H_{1}$ : There is statistically significant correlation between the education of consumers and their preferences for branded products over unbranded products.

The contingency table below (Table 8) provides the frequencies of respondents' answers considering the highest level of education of the respondents.

Table 8. Education vs Branded Products Preferences

\begin{tabular}{|c|c|c|c|c|c|c|c|c|}
\hline & & & 1 & 2 & 3 & 4 & 5 & Total \\
\hline \multirow{6}{*}{ Education } & basic/apprentice & Count & 126 & 224 & 420 & 209 & 92 & 1071 \\
\hline & & Expected Count & 100.6 & 229.0 & 422.1 & 246.6 & 72.8 & 1071,0 \\
\hline & secondary & Count & 46 & 143 & 269 & 193 & 36 & 687 \\
\hline & & Expected Count & 64.5 & 146.9 & 270.8 & 158.2 & 46.7 & 687,0 \\
\hline & university & Count & 16 & 61 & 100 & 59 & 8 & 244 \\
\hline & & Expected Count & 22.9 & 52.2 & 96.2 & 56.2 & 16.6 & 244,0 \\
\hline \multirow[t]{2}{*}{ Total } & & Count & 188 & 428 & 789 & 461 & 136 & 2002 \\
\hline & & Expected Count & 188,0 & 428.0 & 789.0 & 461.0 & 136.0 & $2,002.0$ \\
\hline
\end{tabular}


From the point of view of education, there were 3 education intervals set, which are as follows: primary/vocational graduates, secondary graduates and university graduates respectively. The highest frequencies were identified with the primary/vocational graduates (53.5\%). The preferences within all three intervals, however, are rather equally balanced. In case of the primary/vocational graduates and the university graduates, there is a slightly prevailing non-preference for the branded products. As for the secondary graduates, the positive attitudes towards the branded products, compared to the negative ones, exceed the cumulated answers frequencies by $5.8 \%$. The least positive attitudes towards the branded products, i.e., rated 1 on the scale, were identified with the primary/vocational graduates, which are $11.8 \%$ of all respondents within the interval; and the most positive attitudes, i.e., rated 5, were identified also with the primary/vocational graduates (8.6\%). Considering also the other education intervals, it is possible to assume that the higher the education, the more neutral the preferences, and thus one cannot clearly speak of preference vs non-preference for branded products. The most homogeneous appear the university graduates.

Table 9 provides the p-value of the independence test on the correlation between the education of consumers and their preferences for branded products; and it is the same also with this socio-demographic characteristic, i.e., the p-value is lower than the significance level standard value. The $\mathrm{H}_{0}$ hypothesis regarding the independence of the variables is rejected and the alternate hypothesis on the dependency of the variables is accepted. Therefore, it is possible to consider that the consumer's education in terms of socio-demographic characteristics is determining the preferences for and attitudes of consumers towards branded products. The least stable interval in terms of the brand preferences are the primary/vocational graduates, where some of them may have a very positive attitude towards brands, while the others may have a very negative attitude instead. The brand may be a strong argument when it comes to consumer decision-making on products, especially in case of the primary/vocational graduates.

Table 9. Chi-Square Test 3

\begin{tabular}{lccc}
\hline & Value & df & $\begin{array}{c}\text { Asymptotic Significance (2- } \\
\text { sided) }\end{array}$ \\
\hline Pearson Chi-Square & $41.211^{*}$ & 8 & .000 \\
Likelihood Ratio & 42.175 & 8 & .000 \\
Linear-by-Linear Association & 1.199 & 1 & .274 \\
N of Valid Cases & 2,002 & & \\
\hline \multirow{2}{*}{$* 0$ cells $(0.0 \%)$ have expected count } & & \\
\hline
\end{tabular}

* 0 cells $(0.0 \%)$ have expected count less than 5 . The minimum expected count is 16.58 .

Source: Authors' development.

Table 10 provides the Cramer's $V$ coefficient and the contingency coefficient values, proving weak dependency between the variables, i.e., the education of consumers and preferences of consumers for branded products, though statistically significant, and thus the random phenomenon shall not be considered. 
Table 10. Directional Measures 3

\begin{tabular}{|c|c|c|c|c|c|}
\hline & & Value & $\begin{array}{r}\text { Asymptotic } \\
\text { Standard Errora }\end{array}$ & Approximate $T^{b}$ & $\begin{array}{r}\text { Approximate } \\
\text { Significance }\end{array}$ \\
\hline \multirow[t]{2}{*}{ Nominal by Nominal } & Cramer's V & .101 & & & ,000 \\
\hline & $\begin{array}{l}\text { Contingency } \\
\text { Coefficient }\end{array}$ & .142 & & & 000 \\
\hline $\mathrm{N}$ of Valid Cases & & 2.002 & & & \\
\hline
\end{tabular}

a. Not assuming the null hypothesis.

b. Using the asymptotic standard error assuming the null hypothesis.

c. Based on normal approximation.

Source: Authors' development.

The last socio-demographic characteristic subject to analysis was income, which were to determine net monthly income of the household the respondent lives in. The hypothesis is as follows:

Ho: There is no statistically significant correlation between the household income of consumers and their preferences for branded products over unbranded products.

$H_{1}$ : There is statistically significant correlation between the household income of consumers and their preferences for branded products over unbranded products.

The contingency table below (Table 11) shows the frequencies of respondents' answers by individual net monthly income intervals.

\section{Table 11. Income vs Branded Products Preferences}

\begin{tabular}{lrlrrrrrr}
\hline & & & $\mathbf{1}$ & $\mathbf{2}$ & $\mathbf{3}$ & $\mathbf{4}$ & $\mathbf{5}$ & \multicolumn{1}{c}{ Total } \\
\hline & up to 500 $€$ & Count & 44 & 78 & 146 & 51 & 23 & 342 \\
& & Expected Count & 32.1 & 73.1 & 134.8 & 78.8 & 23.2 & 342,0 \\
& $\mathbf{5 0 1 - 1 , 0 0 0} €$ & Count & 73 & 159 & 281 & 141 & 38 & 692 \\
Net & & Expected Count & 65.0 & 147.9 & 272.7 & 159.3 & 47.0 & 692,0 \\
monthly & $\mathbf{1 , 0 0 1 - 1 , 5 0 0} €$ & Count & 42 & 115 & 215 & 143 & 43 & 558 \\
household & & Expected Count & 52.4 & 119.3 & 219.9 & 128.5 & 37.9 & 558,0 \\
income & $\mathbf{1 , 5 0 1 - 2 , 0 0 0} €$ & Count & 18 & 52 & 103 & 66 & 16 & 255 \\
& & Expected Count & 23.9 & 54.5 & 100.5 & 58.7 & 17.3 & 255,0 \\
& $\mathbf{2 , 0 0 1 - 2 , 5 0 0} €$ & Count & 3 & 15 & 27 & 36 & 7 & 88 \\
& & Expected Count & 8.3 & 18.8 & 34.7 & 20.3 & 6.0 & 88,0 \\
& \multirow{2}{*}{ over 2,500 $€$} & Count & 8 & 9 & 17 & 24 & 9 & 67 \\
& & Expected Count & 6.3 & 14.3 & 26.4 & 15.4 & 4.6 & 67,0 \\
\hline Total & & Count & 188 & 428 & 789 & 461 & 136 & 2002 \\
& & Expected Count & 188,0 & 428.0 & 789.0 & 461.0 & 136.0 & $2,002.0$ \\
\hline & & & & & Source: Authors' development.
\end{tabular}

For the purpose of analysing this socio-demographic characteristic, there were 6 net monthly income intervals set, each of them in EUR 500 increments, and the frequencies of responses were expected not to be much equally balanced within the intervals, assumption which was proved afterwards. The highest frequencies (692) were identified for the interval EUR 501-1,000, i.e., $34.6 \%$ of the total number of respondents. The rather neutral attitude (rated 3) definitely prevails in all intervals of up to EUR 2,000, and, moreover, it is the first time, the rather neutral attitude is not the representative one of all income intervals. The respondents living in households with net monthly income of over EUR 2,001 are clearly to opt for the branded products, that is, $48.9 \%$ in the interval EUR 2,001-2,500 and $49.3 \%$ in the interval over EUR 2,500 respectively; thus, the higher the income, the rule the higher the preferences for branded products applies. 
The column Asymp. Sig. (2-sided) in Table 12 provides the resulting p-value of the independence test on correlation between the net monthly household income of consumers and their preferences for branded products over unbranded products. Regarding the pvalue, which is lower than the significance level standard value, the $\mathrm{H}_{0}$ null hypothesis regarding the dependency of the variables is rejected and the alternate $\mathrm{H}_{1}$ hypothesis is accepted, i.e. the variables are dependent, and thus the higher the income, the rule the higher the consumer preferences for branded products applies.

Table 12. Chi-Square Test 4

\begin{tabular}{lccc}
\hline & Value & df & $\begin{array}{c}\text { Asymptotic Significance (2- } \\
\text { sided) }\end{array}$ \\
\hline Pearson Chi-Square & $61.781^{*}$ & 20 & .000 \\
Likelihood Ratio & 61.076 & 20 & .000 \\
Linear-by-Linear Association & 31.092 & 1 & .000 \\
N of Valid Cases & 2,002 & & \\
\hline \multicolumn{1}{c}{$* 1$ cells (3.3\%) have expected count less than 5. The minimum expected count is 4 55. }
\end{tabular}

* 1 cells $(3.3 \%)$ have expected count less than 5 . The minimum expected count is 4.55 .

Source: Authors' development.

The Cramer's V coefficient and the contingency coefficient (Table 13) provide more details on the net monthly household income vs branded products preference correlations. Regarding the resulting values of the coefficients involved, a weak dependence between the variables results, i.e., the preference for branded products depends on the consumer's income. Given the p-value, the coefficient significance test of the variables is statistically significant, i.e., the dependence between the variables is weak, though statistically significant, and thus the random phenomenon shall not be considered.

Table 13. Directional Measures 4

\begin{tabular}{llrrr}
\hline & & $\begin{array}{c}\text { Asymptotic } \\
\text { Standard Error }\end{array}$ & Approximate Tb & $\begin{array}{r}\text { Approximate } \\
\text { Significance }\end{array}$ \\
\hline Nominal by Nominal & Cramer's V & .088 & .000 \\
& $\begin{array}{l}\text { Contingency } \\
\text { Coefficient }\end{array}$ & .173 & .000 \\
N of Valid Cases & & 2,002 & \\
\hline
\end{tabular}

a. Not assuming the null hypothesis.

b. Using the asymptotic standard error assuming the null hypothesis.

c. Based on normal approximation.

Source: Authors' development.

\section{Discussions}

The decision to buy a particular product is influenced by several socio-demographic characteristics such as income and household size, age and education of the head of the family, race and ethnicity (Bouhlal and Capps, 2016). Valaskova et al. (2018) conclude that the attitudes of respondents towards the private label products are dependent on some demographic determinants - the respondent's age, income and status. In all three cases, there is a weak dependence between the determined demographic determinants and consumers' attitudes. Those customers who purchase private label products more often also identify the reasons for their purchase - cost effectiveness, quality, and loyalty to the retailer. The status of the respondent significantly affects the type of private label products a consumer buys, due to the social and financial elements related to the consumer's family status. Richardson et al. (1994) published a detailed study in which they argue that the 
consumer's tendency to buy private label products depends on certain demographic factors (income, family size, age, education) as well as specific consumer perceptions about particular product categories.

The reality in the market has shown that traditional brand management theory lacks success. There is a need to provide a revision to this theory with an emphasis on behavioural approach. In contemporary times, the theory has been limited mainly to this criterion and avoided the exact identification of specific brand value sources in conditions of particular nations (Kliestikova et al., 2019) or according to the sustainable development goals evolution and correlations (Fonseca et al, 2020).

It is necessary to underline that preferences for branded products may differ significantly with individual consumers. Moreover, it is not possible to define the branded product explicitly, i.e., what some consumers would recognize in the branded product, the others will not, and would rather find it just as reference product of no added value. However, almost each product on the market is associated with a particular brand, and which is then distinguished by the level of personification of the brand, brand characteristics, market power and position of the brand in terms of competitiveness.

The powerful brands reflect consumer needs and, figuratively speaking, personal or emotional values, which are all together to make strong and stable consumer preference for the brand in terms of a functional product. The single brand usually does not allow for monopolizing the market, especially in the case of rather differentiated markets. Should the company increase its market share, it has to pursue the multiple brand strategy, which is also to build up the company portfolio. Furthermore, should the company is to grow, and thus to win new markets and/or open new distribution channels, it has to build new brands; and, otherwise, should the brand is not attractive anymore, and thus not profitable, the company is better to get rid of the brand, i.e., merge, sell, milk or kill the brand.

The survey data were used to test the statistical hypotheses that proved the correlation between consumer preferences for branded products vs selected sociodemographic characteristics in the target group. It shows the weak correlation in all cases, though statistically significant, and thus the random phenomenon shall not be considered. The above-mentioned also proved that the socio-demographic characteristics of consumers have definitely to be considered when working out and implementing the branding strategies. The companies are not able to set the socio-demographic trends or affect them somehow, but they are still able to monitor, assess and evaluate the current trends reliably to predict the future trends, and thus to adopt them. Moreover, most socio-demographic data are handled by competent regulatory authorities, who monitor and keep the data upto-date, and make them available to companies, who are thus to cut the other costs for data processing.

Given the survey findings, current brand management trends and subjective consumer brand preferences, it is to proceed to formulating conclusions, fundamental hypotheses and recommendations that would take into account the socio-demographic characteristics, and thus allow for more efficient implementation of the branding strategies to practice:

- profile of consumer mostly preferring branded products - male, 36-45 years old, secondary graduate, net monthly household income over EUR 2,500;

- profile of consumer least preferring branded products - female, 16-25 years old, primary or vocational graduate, net monthly household income up to EUR 500; 
- consumer preferences for branded products are determined by the gender of the consumer - male consumers, compared to female consumers, tend to prefer branded products over unbranded ones much strongly, what may depend on a number of factors: different values, different lifestyles, more demand for technical products, higher salaries, etc. whereas female consumers also tend to prefer branded products over unbranded ones, but their preferences are more likely to be restricted mainly to clothing and cosmetics, since they tend to be rather emotional and more intense in feelings, and thus they are more likely to follow the latest fashion trends; moreover, they would even not mind to pay a higher price for branded products, especially for clothing and cosmetics products, which the sellers are aware of, thus trying to make use of that, i.e., by putting so called "pink tax" on those product categories;

- consumer loyalty to brand varies according to the age of the consumer - the rule the older the consumer, the stronger the loyalty applies, which favours the brands that are to target the consumers of elder age groups, employees, whereas as for the consumers of younger age groups, branded products are not a priority but rather a wise choice or a specific need as the matter of choice; consumer preferences for branded products, however, are following a downward trend towards the end of their life as employee;

- consumer's loyalty for the brand is determined by the age of the consumer consumers of younger age groups are more easily influenced, they like to try new things and thus easily follow new trends and innovations, and since they tend to act rather spontaneous, they would easily change their mind to opt for any other product brand;

- education has little effect on consumer's preferences - consumer's education has less effect on his/her preferences and attitudes towards brands; moreover, the primary/vocational graduates consumers are likely to differ in their preferences, and such the market segment would thus involve either the brand's fans or the non-fans; moreover, the rule the higher the education, the lower the effect applies, i.e., consumers would tend to become more neutral or homogenous in their preferences for branded products with higher levels of education; and it should be added that education is one of the characteristics that are to be affected directly by the consumer;

- income has positive effect on consumer's preferences - the rule higher the income, the higher the demand for branded products applies; the profit margin on branded product shall be set pro rata the purchasing power of consumers; moreover, notably the global brands shall pursue a policy of price differentiation, which is to consider the disposable income of consumers in a given market;

- product type affects consumer's preferences - the mind-set on the product brand is more effective with the durables and/or unusual products than with the nondurable (or consumables), which is due to the consumer being more deeply involved in the decision-making about the unusual products.

Existing studies overwhelmingly comment on consumers' socio-demographic characteristics as important determinants in their purchasing behaviour and decision- 
making, including the purchase of branded products. Based on the results of the research conducted, it is possible to identify with the opinions in published studies. Within the research, the identical survey will be carried out in the year to come. The purpose of this future survey is to identify the development of the influence of socio-demographic characteristics of consumers on their preferences in relation to branded products.

\section{Conclusions}

The findings of the survey proved that effective branding strategies shall, inter alia, pursue the socio-demographic trends. The socio-demographic characteristics of consumers (gender, age, education, income) we analysed are considered the key determinants affecting the attitudes and preferences of consumers for branded products; and it is not possible to implement branding strategies not considering the number of other characteristics and indicators (profitability, risk level, loyalty to brand, consumer satisfaction index, brand interactions, competitiveness, etc.), which play also the key part in strategic decisionmaking about brands. Moreover, the loyalty to brand brings significant marketing benefits, including those of reducing marketing costs, rising market value, lowering competitive brand adoption rate, rising profits, etc. The socio-demographic characteristics, however, differentiate the markets, including the branded product markets; and thus, the monobrand market cannot satisfy all consumer needs relative to all market segments. Nevertheless, existing micro-markets and changing consumer needs entail the need for high variability and diversity of the brands which can be defined as the unique set of characteristics and added values. The socio-demographic characteristics of consumers shall therefore be considered the reliable selection criterion for determining both the attractiveness and potential of the brand in terms of its success. Research results should be used when designing strategies for brands, focusing on the specific requirements and needs of individual consumer groups, by accepting their demographic differences.

\section{Acknowledgement}

This research was financially supported by the Slovak Research and Development Agency Grant No.APVV-15-0505: Integrated Model of Management Support for Building and Managing the Brand Value in the Specific Conditions of the Slovak Republic.

\section{References}

Aaker, D. A. (1996). Measuring brand equity across products and markets. California Management Review, 38(3), 102-120.

Aurier, P. \& Séré de Lanauze, G. (2012). Impacts of perceived brand relationship orientation on attitudinal loyalty: An application to strong brands in the packaged goods sector. European Journal of Marketing, 46(11/12), 1602-1627.

Bouhlal, Y. \& Capps, O. (2012). The Impact of Retail Promotion on the decision to purchase private label products: The case of U.S. processed cheese. Agribusiness, 28 (1), 15-28.

Bowden, J. L. H. (2011). Engaging the student as a customer: A relationship marketing approach. Marketing Education Review, 21(3), 211-228.

Chaudhuri, A. \& Holbrook, M. B. (2001). The chain of effects from brand trust and brand affect to brand performance: The role of brand loyalty. Journal of Marketing, 65(2), 81-93. 
Cho, E. \& Fiore, A. M. (2015). Conceptualization of a holistic brand image measure for fashion-related brands. Journal of Consumer Marketing, 32(4), 255-265.

Dima, M.A, Ghinea, V (2016). A model of Academic Leadership, Book Series: Proceedings of the Conference on European Management Leadership and Governance, 12th European Conference on Management, Leadership and Governance (ECMLG), Natl Univ Polit.

Dincă, V. M., Dima, A. M., \& Rozsa, Z. (2019). Determinants of cloud computing adoption by Romanian SMEs in the digital economy. Journal of Business Economics and Management, 20(4), 798-820. https://doi.org/10.3846/jbem.2019.9856.

Evanschitzky, H., Iyer, G. R., Plassmann, H., Niessing, J. \& Meffert, H. (2006). The relative strength of affective commitment in securing loyalty in service relationships. Journal of Business Research, 59(12), 1207-1213.

Fonseca, L, Domingues, J.P. Dima, M.A. (2020). Mapping the Sustainable Development Goals Relationships. Sustainability, 12(8), article no 3359

Gill, M. S. \& Dawra, J. (2010). Evaluating Aaker's sources of brand equity and the mediating role of brand image. Journal of Targeting, Measurement and Analysis for Marketing, 18(3), 189-198.

Grubor, A. \& Milovanov, 0. (2017). Brand Strategies in the Era of Sustainability. Interdisciplinary Description of Complex Systems, 15(1), 78-88.

Iglesias, O., Ind, N. \& Alfaro, M. (2013). The organic view of the brand: A brand value cocreation model. Journal of Brand Management, 20(8), 670-688.

Iglesias, O., Markovic, S., Singh, J. J. \& Sierra, V. (2019). Do Customer Perceptions of Corporate Services Brand Ethicality Improve Brand Equity? Considering the Roles of Brand Heritage, Brand Image, and Recognition Benefits. Journal of Business Ethics, 154(2), 441-459.

Iglesias, 0., Singh, J. J. \& Batista-Foguet, J. M. (2011). The role of brand experience and affective commitment in determining brand loyalty. Journal of Brand Management, 18(8), 570-582.

Kim, K. H., Jeon, B. J., Jung, H. S., Lu, W. \& Jones, J. (2012). Effective employment brand equity through sustainable competitive advantage, marketing strategy, and corporate image. Journal of Business Research, 65(11), 1612-1617.

Kliestikova, J., Durana, P. \& Kovacova, M. (2019). Naked Consumer's Mind Under Branded Dress: Case Study of Slovak Republic. Central European Business Review, 8(1), 15-32.

Krizanova, A., Majerova, J., Kliestik, T. \& Majercak, P. (2013). Theoretical Aspects of Brand Building in Seafood Industry. Nase More, 60(5-6), 105-112.

Kuchinka, D.G.J., Balazs, S., Gavriletea, M.D. \& Djokic, B.B. (2018). Consumer Attitudes toward Sustainable Development and Risk to Brand Loyalty. Sustainability, 10(4), 997.

Lei, S. \& Chu, L. (2015). The mediating role of consumer satisfaction in the relationship between brand equity and brand loyalty based on PLS-SEM Model. Int. Bus. Res., 8, 62-70.

Levy, S.J. \& M.K. Luedicke (2013). From marketing ideology to branding ideology. Journal of Macromarketing, 33(1), 58-66.

Melián-González, S. (2018). What Do Consumers Appreciate about On-Demand Economy Workers? Psychosociological Issues in Human Resource Management, 6(2), 29-43. 
Merz, M. A., He, Y. \& Vargo, S. L. (2009). The evolving brand logic: A service-dominant logic perspective. Journal of the Academy of Marketing Science, 37(3), 328-344.

Moravcikova, D., Krizanova, A., Kliestikova, A. \& Rypakova, M. 2017. Green Marketing as the Source of the Competitive Advantage of the Business. Sustainability, 9(12), art. no. 2218.

Nica, E. \& Taylor, L. (2017). New media technologies, digital sharing, and the neoliberal economy. Ekonomicko-manazerskespektrum, 11(2), 103-110.

Ogba, I. E. \& Tan, Z. (2009). Exploring the impact of brand image on customer loyalty and commitment in China. Journal of Technology Management in China, 4(2), 132-144.

Okuneviciute Neverauskiene, L. \& Pranskeviciute, I. (2018). Overcoming paradox for social enterprise definition: Case of Lithuania. Ekonomicko-manazerskespektrum, 12(1), 104-118.

Park, H. J. \& Rabolt, N. J. (2009). Cultural value, consumption value, and global brand image: A cross-national study. Psychology and Marketing, 26(8), 714-735.

Popović, V., Miljković, J. Ž., Subić, J., Jean-Vasile, A., Adrian, N., \& Nicolăescu, E. (2015). Sustainable land management in mining areas in Serbia and Romania. Sustainability, 7(9), 11857-11877.

Richardson P. S., Dick A. S. \& Jain A. K. (1994). Extrinsic and intrinsic cue effects on perceptions of store brand quality. Journal of Marketing, 58 (4), 28-36.

Rimarcik M. (2007). Statistika pre prax. Bratislava: Vydavatel'stvo: Marián Rimarčík.

Shackelford, V. (2018). The Neurocognitive Consequences of Facebook Addiction. American Journal of Medical Research, 5(1), 97-102.

Sierra, V., Iglesias, O., Markovic, S. \& Singh, J. J. (2015). Does ethical image build equity in corporate services brands? The influence of customer perceived ethicality on affect, perceived quality, and equity. Journal of Business Ethics, 144(3), 661-676.

Singh, J. J., Iglesias, O. \& Batista-Foguet, J. M. (2012). Does having an ethical brand matter? The influence of consumer perceived ethicality on trust, affect and loyalty. Journal of Business Ethics, 111(4), 541-549.

Susanty, A. \& Kenny, E. (2015). The Relationship between Brand Equity, Customer Satisfaction, and Brand Loyalty on Coffee Shop: Study of Excelso and Starbucks. Asean Mark. J., 7, 14-27.

Valaskova, K., Kliestikova, J. \& Krizanova, A. 2018. Consumer Perception of Private Label Products: An Empirical Research. Journal of Competitiveness, 10(3), 149-163.

Vysekalova, J. \& Mikes, J. (2009). Image a fireman identita. Praha: Grada Publishing a.s.

Wagner, T., Hennig-Thurau, T., \& Rudolph, T. (2009). Does customer demotion jeopardize loyalty? Journal of Marketing, 73(3), 69-85.

Yang, Y. C. (2012). High-involvement human resource practices, affective commitment, and organizational citizenship behaviors. The Service Industries Journal, 32(8), 12091227.

Zambardino, A. \& Goodfellow, J. (2007). Being 'affective' in branding? Journal of Marketing Management, 23(1-2), 27-37. 